Fernando Figueiredo Balieiro

Universidade Federal de Santa Maria, Santa Maria, RS, Brazil

\title{
Consuming Carmen Miranda: Dislocations and dissonances in the reception of an icon
}

\begin{abstract}
From the perspective of cultural studies, in its dialogs with feminist and queer studies, this article analyzes the identification of various publics with Carmen Miranda based on the consumption of her filmic, musical and artistic products, accessing her professional trajectory in its imbrication with its various forms of reception. The focus will be on the negotiations of the artist with her publics, touching on how her career involved reconfigurations concerning aspects of gender, race and sexuality. It is based on a perspective that considers the dynamism of mass culture, considering possibilities for various forms of appropriation of cultural products, as well as shifts and dissonances in receptions. To analyze these aspects, the paper focuses on feminine receptions in Brazil and the United States, and those of a male homosexual public contemporary to her career.
\end{abstract}

Keywords: Carmen Miranda; Mass Culture; Consumption; Negotiations; Dislocations

\section{(c) (i)}

Esta obra está sob licença Creative Commons.

1 Translated by Jeffrey Hoff. This article presents results of my dissertation which was funded by CNPq and CAPES (PDSE/Process number $8112 / 12-6$ ).

\section{Introduction ${ }^{1}$}

August 12, 1955 was marked by an episode that stirred a national commotion. The body of Carmen Miranda arrived in Rio de Janeiro from Los Angeles and was taken by the fire department to the old city council building for viewing. Thousands of people in the procession paid homage when the coffin wrapped in a Brazilian flag was removed from the vehicle and taken for public viewing for a day. The crowd in front of the city council indicated the population's desire to see the face of their idol up close for the last time. On the next day, the firemen took the body to the cemetery of São João Batista, accompanied by thousands of people. According to biographer Abel Cardoso Junior, at the wake, "from $1 \mathrm{pm}$ on that day, until $1 \mathrm{pm}$ on Aug, 13, more than 60,000 people passed before the body (1978, p. 30). More impressively, her burial was accompanied "by between 500,000 and one million people - it was the most widely attended in the history 
2 Within the logic of the mass market, the appeal to the consumer is the fundamental factor, producing ties between individuals and goods with strong emotiona implications. The idea of identification is based on the concept that identity emerges "between the concepts and definitions that are represented to us by the discourses of a culture and by our desire (conscious or unconscious) to respond to the appeals made by these meanings, that we be interpellated by them" (HALL, 1997, p. 26).

3 The internationally known production Carmen Miranda: Banana is my business, by Helena Solberg (1995) stands out.

${ }^{4}$ In Brazil, they include the works of Simone Pereira de Sá (1997), Ana Rita Mendonça (1999), Tania Garcia Costa (2004) and Mônica Schpun (2008). In the internationa literature I highlight the works of Shari Roberts (1993), José Ligiero Coelho (1998), Priscilla Peña Ovalle (2011) and Lisa Shaw (2013). of Rio, stirring deep popular reaction (...) 8 days after her death" (JUNIOR, 1978, p. 30).

Eight days earlier, on August 5, 1955, Carmen Miranda had a heart attack at her Beverly Hills home hours after nearly fainting on the Jimmy Durante television program. Born in Portugal, she became an icon on Brazilian radio, but for most of her career worked in the United States. She became a star of Hollywood movies, a famous nightclub entertainer, and appeared in a number of early television programs. She was a unique personality who accompanied the development of the mass media and globally promoted female and musical representations and performances that would be linked to Latin America and Brazil. Based on her persona, forms of identification ${ }^{2}$ were established that were felt and experienced, shaped by the worshiping relationship between a musical and movie star and her publics.

There are countless narratives about the life of Carmen Miranda, from film products ${ }^{3}$ to academic studies, ${ }^{4}$ all justified because they regard a paradigmatic figure of the mass culture produced in the 1930s and 1940s. What can an already so well-known national and international icon bring that is new to a sociological analysis of products of mass culture and their publics?

This article will analyze a dynamic and multifaceted aspect that involves the representations of Carmen Miranda and her consumption by distinct publics, causing the negotiation of values to infiltrate the artist's aesthetic choices and produce varied and dissonant meanings in their readings. Far beyond the broadly recognized representations of "Brazilianess" and Latin America, Carmen offered the public possibilities for new performances of gender and sexuality, shifting meanings through the negotiation of moral values and humor.

To analyze these questions, I begin by operationalizing Judith Butler's concept of performativity (2003). Conceptualizing gender identity as a performative construction, Butler (2003) begins not from a structure that determines the subject "from top down", but from a construction that takes place in the individual's action, within the limits of the symbolic contexts and the representations available (cf. SALIH, 2012). For Butler, a performance is based on a given framing, but can be dislocated from its previous meanings, to the degree to which the meanings are open to resignifications. In this sense, I address how Carmen manipulated certain meanings specific to her persona and film characters, negotiating meanings in the way that she related with various publics. Beyond her performances, I focus on Carmen Miranda's dislocating appropriations that allowed for meanings that were dissident to their conventional readings. 
${ }^{5}$ The article by Shari Roberts (1993) explores this element, characterizing it as a crucial aspect of the agency of the entertainer based on which she established a special communication with her public. According to Roberts, Carmen had fans predominantly from the feminine public because her action was not merely the confirmation of a negative stereotype, but a type of parody of it, based on her feminine and ethnic excess.

${ }^{6} \mathrm{~F}$ or an introduction to Cultural Studies, see CEVASCO, 2003 and MATTELART \& NEVEU, 2004.

\footnotetext{
${ }^{7}$ Richard Dyer (1979), focusing on the theme of stars as a socia problematic, also offers a critical reading of the structural and economistic analyses. Dyer (1979) emphasizes that if the studios in fact construct the image of a sta and her shapes and stimulate her appeal to the public, this creation does not take place unilaterally, but in a more complex and nuanced manner. In these terms, stars are not only created through a vertical logic imposed by the studios, but are realized in consumption and depend on the audience. What attests to this affirmation is the very oscillation in the career of the stars, which goes beyond any model based on a sovereign manipulation that considers reception to be passive, as only a response.
}

This article focuses on the consumption of her images and performances by two publics: the female public ${ }^{5}$ in Brazil and the United States and the male homosexual public of her time. To do so, the theoretical perspective used will be that of cultural studies, ${ }^{6}$ in particular its influences on feminist and queer theories. The central presumption contained in the reflexes proposed here is that consumption--specifically the consumption of an icon of mass culture--an apparently private and economic activity, is moved by symbolic aspects and saturated by political questions and power relations.

For a long time, the theme of consumption of products of mass culture was addressed predominantly by Marxist literature, which focused on the alienation contained in its industrial form of production. Critical of this view, Jesus MartínBarbero (2009) offers a fruitful perspective for considering the centrality of consumption in the dynamics of production of mass culture. Instead of presupposing mass culture as a form of degradation of erudite culture, in a criticism of the classic Frankfurtian interpretation, Martín-Barbero (2009) proposes an approach that is attentive to reception and understands that mass culture is slowly generated by the logic of consumption. Instead of conceiving consumption as unilaterally determined by its industrial production, it focuses on previous social experiences and on demands of certain individuals to understand how consumption decisively influences the logic of mass cultural production.

Concerning the objectives of this article, Martín-Barbero (2009) conceived of the star system 7 as a "commercial device involving mechanisms of popular perception and recognition" (2009, p. 203), that is, he presupposes the idea that the construction of the image of the star depends on a symmetry with the identification of the public: "it was the identification felt and the desire mobilized by the 'star' that made films profitable" (2009, p. 204). Conferring greater dynamism to the process of codification and decodification of mass cultural products, Martín-Barbero (2009, p. 176) proposes "shifting the reading from the ideological field to read not only the dominant logic, but also the different logics in conflict in both production and consumption", considering consumption between the "interlinking of submissions and resistances, impugnations and complicities" (MARTíN-BARBERO, 2009, p. 268). Using these reflections, and striving to go beyond the author's view that is focused on the dynamics of consumptions and social classes, I also explore the dimensions of race, gender and sexuality present in Carmen Miranda's performances, which are interlinked with the appropriation of her image and performances by various publics.

Filling this gap, Miriam Adelman (2009) summarized how, within a feminist perspective, the importance of the 
consumption of mass culture was emphasized in the redefinition of gender divisions that were part of the large changes that took place during the twentieth century. In synthesis, it involves a period in which:

Public space begins to lose its characteristics as a male domain to the degree to which women - both as workers in the consumption sector and as consumers of leisure and culture - begin to frequent the new spaces of large stores and movie theaters. If, as some theoreticians correctly indicate, this certainly generated new modes of control over women, the new scenario was not limited to disciplining, because the genderized history of various forms of consumption (from films to cosmetics; cf. Peiss, 1996; Carter, 1996; Ewen \& Ewen, op. cit., among others) show that women's access to "the products of modernity" have an important role in dismantling systems of social and family authority that exercise very direct controls over their personal and sexual autonomy. (ADELMAN, 2009, p. 188-9)

In relation to the filmic products, within a contemporary feminist perspective Robertson (1996) focuses on consumption not taking as given a voyeuristic male gaze, but by considering the distinct forms of reading of the films and representations of the feminine, with an emphasis on feminine receptions. Also related to this aspect, there is considerable production about the relationship between cinema and gay men (DYER, 2004, p. 164), and about the aesthetic of musicals and their specific reception by these individuals (HALPERIN, 2012 , p. 104). These studies look at the influence of certain types of female personalities on this public (CLETO, 1999; DYER, 2004; HALPERIN, 2012), which constitutes a "camp" form of reading filmic products, subverting their conventional meanings.

In keeping with these contemporary perspectives, I propose an intersectional reading (BRAH, 2006) of the trajectory of Carmen Miranda, addressing how aspects that involve race, gender, sexuality and class are present in her performances, considering that her career spanned different national contexts and with them different discursive framings and publics, which were connected by economic, cultural and political relations that were reinforced in that period. In this way, the analysis of her trajectory will seek to interpret the inseparability of her performances from all the symbolic values imposed on them, considering the expectations of the publics: on one hand, presenting limits and possibilities to her representations, and on the other, expressing the multiplicity of meanings that can be captured from their various appropriations. To do so, the analysis will focus not 
${ }^{8}$ For the analysis of the trajectory and the relationship between Carmen Miranda and her publics, I visited archives in São Paulo, Rio de Janeiro, San Francisco, Los Angeles and New York, including the Biblioteca Jenny Klabin Segall, as well as its digitalized archives that include the magazines Cena Muda and Cinearte; the Museu Carmen Miranda; the Biblioteca Nacional; the GLBT Historica Society Archive; the Margareth Herrick Library at the Academy of Motion Pictures Arts and Sciences; the One Lesbian and Gay Archive and the Shubert Archive. on her participation in films or musical productions, but on the reception and communication of Carmen Miranda with the public through the press, which is accessible by means of document analysis which was made possible by visits to Brazilian and foreign archives. $^{8}$

\section{Negotiating identities between the desires of two nations}

To review Carmen Miranda's performances in the first phase of her career during the 1930s requires a reflection about the specific context of production of national identity, in particular the first connection of this identity with radio and popular music. At this time, not only was samba transformed into a national rhythm, but it redimensioned the national symbolic universe by incorporating popular and Afro-Brazilian cultural elements. This entire process accompanied the development of a market for mass culture in Rio de Janeiro, which was then the Brazilian capital, especially since the 1920s and 1930s, with the effervescence of popular theaters, commercial radio and the phonographic industry ( $\mathrm{Cf}$. FENERICK, 2005; DAVIS, 2009). In this period, we began to think, based on the mass media, as a mestizo, racially harmonious country and as a happy people whose greatest expression would be samba.

This symbolic national redimensioning involves complex economic logics from the market of mass culture, as well as political mediations. The state appropriated the success of samba, seeking to intervene in the content of the lyrics and present them as a national rhythm in keeping with the cohesion sought by the Getúlio Vargas government. Meanwhile, the market sought broad acceptance of samba and through a selection of representations incorporated popular music and that of Afro-Brazilian origin, but rejected presenting it in relation to blackness. Even considering the importance of black musicians and composers of the period, the cultural production sought to promote representations marked by whiteness, understood in symbolic terms as a synonym of civility.

In this context, the urbanized Brazilian capital accompanied the global economic and cultural transformations, establishing a market of leisure and entertainment with rich cultural production. There was simultaneously a shift in Brazil from a predominantly French cultural reference to that from the United States, particularly influenced by mass culture, which promoted consumption habits and practices. The access to the new lifestyle was marked by boundaries of social class, which defined certain types of leisure for privileged social groups, such as casinos

Estudos Feministas, Florianópolis, 25(1): 269-290, janeiro-abril/2017 273 
and clubs and others that were more accessible to the middle and lower classes, such as movies and bars. Whiteness thus expressed an affinity with the modern world in its material and symbolic dimensions that selectively define who has access to certain products, spaces and behaviors that promoted mechanisms of social distinction. The possession of radio, the incorporation of Hollywood fashions, a presence at fancy balls or casinos were some of the elements that linked individuals to modernity. In contrast, various expressions of popular and Afro-Brazilian culture continued to be criticized in the press as "barbaric".

Although aspects of social class and life styles were central, the racial aspect appeared to be tied to them as a mechanism of social distinction. For example, although black musicians and composers gained certain recognition, they did not attain the status of the radio stars, earning lower salaries and not achieving the same prestige. In contrast, the radio stars established a type of Brazilian star system, with notable presence in advertising, in illustrated magazines and in the emerging national cinema, and were closely followed by the Brazilian public. This racial frontier coexisted with a paradoxical valorization of miscegenation and of AfroBrazilian scenarios and rhythms that became part of the national identity.

Carmen Miranda is representative of this period. She had close contact with popular composers and musicians, but achieved success that was unimaginable to her musical companions. She was able to enter spaces for the elite, gain a presence in advertising, magazines and in the emerging national cinema, and after her consecration, and the internationalization of her career, she was already conceived as an artistic representative of the nation. Carmen Miranda's whiteness was key to her broad acceptance. At the peak of her career she incorporated the personality of the Baiana [a woman from Bahia] to the film "Banana da Terra", filmed in late 1938. In this film, she appears in a musical number interpreting the song "O que é que a baiana tem?" [What is it about Bahian Women] by Dorival Caymmi, dressed like a typical Baiana who sold goods on the street.

The character of the Baiana refers both to an authentic Brazil, from Salvador which was the first capital of colonial Brazil, and is a reference to the popular black women who sold typical foods on the streets of Rio de Janeiro. They were religious leaders and had an important presence in ludic and religious spaces of samba, before being commercially promoted. Since the late nineteenth century the Baiana was also a character in theatrical revues, associated to the role of the sensual "mulata", in the process of becoming transformed into a national symbol. 
Carmen balanced herself amid these racial tensions, achieving broad acceptance by audiences in distinct social and symbolic spaces. Carmen portrayed a stylized Baiana who incorporated certain elements of the Baiana character, but rejected those that were considered to be "vulgar". Carmen's interpretation of the Baiana took on other forms than that of the black Baiana, maintaining and shifting its previous meanings. In addition to being white with green eyes, Carmen showed she was in harmony with Hollywood fashion, having a career recognized for the innovations she inspired in Brazilian fashion based on her sewing abilities and a sensibility for adoption of avant-garde aesthetic standards. Carmen's whitened Baiana, alluding to negritude and to the popular, represented the possibility to reconcile the promises of racial harmony with national unity, without breaking with whiteness.

Nevertheless, the whitened incorporation of the Baiana involved a series of ambiguities. Carmen Miranda's interpretations used popular language and humor with dual meanings and allusions to sexuality, as well as glances and winks in complicity with the public, methods typical of popular burlesque theater. Carmen's lyrics incorporated popular language that was discordant from formal Portuguese, in addition to religious elements of African origin. Her songs often expressed values contrary to the official labour ideology, raising fissures and ambiguities in the whitening of samba. Many of Carmen's songs emphasized irreverent fun in relation to romantic commitment or work, inverting the normative gender expectations.

Balancing these racial and moral tensions, in dialog with various publics, she became one of the most consecrated artists of her time and made the Baiana a national symbol. At the peak of her career, she performed in elite social and symbolic spaces of Rio de Janeiro, highlighted by the international and exclusive Cassino da Urca. It was here that Broadway promoter Lee Shubert offered her a contract for the theatrical revue Streets of Paris. Finding immediate success on New York stages, Carmen soon signed a contract with 20th Century Fox.

Carmen Miranda's travel abroad took on airs of a diplomatic expedition in the cultural arena, and she was recognized as the "Ambassador of Samba", coinciding with the period of the "Estado Novo" (1937-1945), which was intensifying its interest in and support for a cultural policy that emphasized national unity. She migrated to the United States with the status of a representative of the nation, with endorsement and support of the federal government. This was indicated when, shortly before Carmen embarked for the United States, President Getúlio Vargas left "his caretakers 
in Caxambu, Minas Gerais, where he was at a spa, to receive Carmen and the Bando da Lua - who gave him a show at the hotel" (CASTRO, 2005, p. 194). To accompany Carmen to the United States, the musical group the Bando da Lua required governmental negotiations involving Lourival Fontes of the National Department of Advertising and Décio Moura, first secretary of the Brazilian consulate in New York, due to protectionist laws for U.S. musicians. The justification to take the group with the singer was that it provided "genuinely" Brazilian music, to present a "true" Brazilian culture.

In the new context, Carmen brought to U.S. cinema an entire symbolic universe that was consolidated in the market for mass culture developed in Rio de Janeiro. The Brazilian national identity came to be systematically produced in a transnational sphere and mediated by the highly specialized corporate apparatus of 20th Century Fox. From that moment on, it can be said that there was an interlinking of representations. Carmen Miranda carried and stylized the personality of the Baiana in an increasingly sophisticated form. Simultaneously, the long-lasting stereotype in the U.S. cinema of the Latin American woman, marked by passion, musicality and sensuality, was incorporated by Carmen, overlapping the Baiana.

Carmen went to the United States in the period known to be ruled by the so-called Good Neighbor Policy during World War II. It was a period marked by accentuation of U.S. economic and political interests in Latin America, in an effort to avoid the influences of the Axis countries. During this period, Carmen Miranda was the lead character in many films that emphasized the idea of Pan Americanism, or that is, of a friendship among the American nations (GARCIA, 2004; MENDONÇA, 1999). Carmen appeared on stage in many musicals with a Latin American theme, flaunting sambas and later mixtures of rhythms and expressions in Portuguese, Spanish and English, representing Latin America, in keeping with the U.S. representation of a cohesive unity. This unity was synthesized as primitive, female and sexualized, in contrast with the civilized U.S. neighbor, which was civilized, male and rational.

\section{Consuming Carmen Miranda: what is it about the baiana in these different contexts?}

Carmen Miranda became a national star in the Brazilian entertainment market who was forged in Rio de Janeiro and later a star on Broadway and in Hollywood. As such, she negotiated broad cultural values mediated by the communication media with a specific history and logic. Her 
career can be approached by beginning with these ties to a public sphere based in mass culture, through which her images and performances were globally promoted.

In the words of Sevcenko, as a mark of the first third of the twentieth century, radios encouraged "first creating myths then penetrating and promoting with stardom the most palpitating details of their private lives. The ideal project for this would be a chain of idols-fans-dramas-bombastic releases and audience hits" (SEVCENKO, 1998, p. 591). Carmen Miranda not only participated in the flourishing of stardom, but was a key figure, handling the interlinking of the various media present in Rio de Janeiro, emphasizing her appearance in public spaces and innovating based on values that became central in the period and that dictated behavior sanctioned as modern. Even before her consecration as a singer, Carmen was very close to cinema, whether because of her looks or her efforts to appear in the emerging Brazilian cinema.

Three years before Carmen recorded her first record, her smile was seen in the Brazilian magazine Selecta, in July 1926, in the article "Quem será a rainha do cinema brasileiro?" [Who will be the queen of Brazilian cinema?"], although her name was not mentioned (CASTRO, 2005, p. 46). Shortly later, another photo of Carmen was published in the magazine Cinearte as a candidate to participate in a film that was announced as the most ambitious of Brazilian cinema (CASTRO, 2005, p. 46). With this effort rejected, her trajectory in movies only began after she became established as a radio star, given that in the primordial years of the Brazilian film industry many people in movie casts were stars on Brazilian radio. Carmen performed in Carnaval Cantado (1932), Alô, alô Brasil! (1935), Estudantes (1935), Alô, alô, Carnava!l (1936) and Banana da Terra (1938), films that circulated in Brazilian cinemas in various regions, giving spectators the opportunity to see the moving image of their star, who until then had been only a voice.

In middle and upper class homes, magazines became popular, and indicators of new socially sanctioned behavior. In addition to the lives of Hollywood movie stars, the magazines featured stars of Brazilian radio, their samba presentations and performances at carnivals that began to be held in theaters and clubs of high society. The sounds were broadcast by radios that were also increasingly present in homes, while the images, opinions and personal life of the new stars were printed on the pages of the magazines.

Rhythms, dances and corporal performances came to be the object of special attention, highlighting female bodies. New standards and values related to leisure, the public sphere and mass culture began to be commercially 
${ }^{9}$ Using an analysis of legal discourses and criminal proceedings about "deflowering", Caulfield (2000) found that despite historic changes from the turn of the nineteenth to the twentieth century until the 1940s, a morality remained in which a woman's sexua honor, also conceived as "sexua honesty", was considered the foundation of the family, which in turn was the support for the nation. stimulated, which resignified urban spaces that, in turn, were progressively occupied by women. Sueann Caulfield (2000) explored how, on one hand, the representations and practices expressed in these media produced the figure of the modern woman, seen as independent and gifted with sensuality. And on the other hand, Caulfield highlights that with the rise of the image of the "modern woman", social forms of control of women were revised, under the argument of the defense of honor, containing value judgments that were marked by race and class distinctions.

With a colonial history that valued female chastity and the idea that "the reclusion of women of the elite made them morally superior to poor women" (CAULFIED, 2000, p. 29), the problematic arose of how to morally distinguish elite women - who were allocated to a sphere of social respectability - from those of the popular classes, many of them black and mestizo. Tiago Gomes (2004) demonstrated how a certain criticism of modernity became established in the 1920s, comparing it to a racialized barbarism. In this racialized vision, under the strong impact of Afro-American and Afro-Brazil music, the image of the modern woman was criticized because it was supposedly assimilated to women of African origin, linking modernity with blackness. At that time, a "panic [arose] in relation to what appeared to many observers to be the sexualization, feminization and dissolution of boundaries of race and class in the public space of large cities" (GOMES, 2004, p. 146-7). Moreover, despite the substantial social transformations, it was still understood that women should subordinate any other activities to their main role: maternity. ${ }^{9}$

In this context, Carmen Miranda negotiated with her public codes of gender, race and sexuality. At the time, Carmen did not frequent the locations of male sociability of the sambistas, such as the Café Nice and the Café do Papagaio. She was sought at home by those sambistas who wanted to legitimize their careers by proximity with the widely recognized singer. Carmen was accompanied by her father during her presentations, often even on trips through Brazil. According to Davis (2009, p. 124), she learned how to separate her performances of private life from her public persona; distancing herself from bohemian life and emphasizing her ties with family were strategies to affirm herself as a "decent girl". She also would not participate in theatrical revues. In the words of her biographer Abel Cardoso Junior: "at this time, Carmen still had prejudices against the theater and thought she should not descend from her radiophonic pedestal and perform comedy scenes in revues" (1978, p. 68). 
${ }^{10}$ Morenity is a designation marked by polysemy and ambiguity. It is said that someone is moreno [literally brown in Portuguese] to avoid emphasizing her blackness. It is also used to refer to someone who is white who has dark hair. Finally, since that time in history, the term was used to emphasize someone's Brazilianess. Therefore, to become moreno (a man) or morena (a woman) came to be at that time a mark of Brazilian nationality, while mechanisms were established to distinguish between a "natural" morena a nd someone who became that way through time in the sun. Moreover, the morena, like the "mulata", is marked by a sensual characterization in the Brazilian symbolic universe. Carmen Miranda identified herself as morena in an interview with Magalhães Jr. in the magazine Vida Doméstica of July 19301930 when asked if she was born "here in Rio." To say she was morena was a way of affirming her Brazilianity, and she made the affirmation after revealing he Portuguese origin to the public. This broke an agreement she had with the Victor recording company, which believed it was an important marketing strategy to associate Carmen to Brazilianity. 11 Within the various possible examples to be cited, the relationship between femininity and sexual liberty in her lyrics can be seen in the "marchinha" [carnival tune known as "Eu dei" [l gave] (1937) by Ary Barroso, offering sexua dialog full of double entendres.

12 "It" was a Hollywood expression attributed to actress Clara Bow by the writer Elinor Glyn. The expression denoted something that someone had, like special charisma, which distinguished her from other people. In Brazil, given the originality of Carmen's form of singing, acting and presenting herself in public, she came to be considered the "singer of the It" (CASTRO, 2005, p. 39).
The negotiations of the moral codes of gender were intimately related with racial issues. Carmen Miranda, who identified herself as "morena" in her lyrics, ${ }^{10}$ revised the narratives of the sensual mulatta linked to the musical theater revues and even to Brazilian novels from the 1800s. The radio singer, with her ability to incorporate the important cultural signs of her time, spiced up her white origin and appearance, performatizing the miscegenation and giving materiality to the definition of the national feminine type.

Although her songs emphasized a supposedly free and democratic femininity, given that it was experienced based on a feminine $1,{ }^{11}$ in practice - as Caulfield demonstrates (2000) - this involved a privileged historic experience, made clear by the fact that Carmen Miranda had her own automobile, which was a symbol of masculinity of the elite at the time. The possession of a car linked Carmen to the expression of an avant-garde modernized femininity. This characteristic was complemented by her images in magazines and in cinema exuding beauty and sensuality, something that perhaps motivated her entourage of female fans (CASTRO, 2005).

At that time, women organized and struggled to defend their rights, like Patricia Galvão (Pagu), Tarsila do Amaral and many others who criticized the patriarchal family and defended sexual liberty for women. Along with these women, considering that negotiations in the private realm are political, and saturated in power relations, we can reevaluate the central role of key women in the mass culture, such as Carmen Miranda, in the changing of gender codes, by providing their fans new possibilities to experience femininity.

The consumption of the images of women like Carmen could be seen as a form of politicalization of the private, to the degree to which it participated in the renegotiations of the limits of the feminine and the masculine. Carmen Miranda had a significant influence on the feminine public, and was considered a radio star, in harmony with Hollywood fashions, which she creatively incorporated by wearing suits immortalized by Marlene Dietrich in U.S. movies, as well as platform shoes that highlighted her on stage. In a two-way process, she adopted elements of U.S. mass culture, giving them a Brazilian tone while incorporating popular elements, making them more sophisticated based on foreign influences.

Concomitantly, it is impossible to think of Carmen's extraordinary success in isolation from her dialog with popular culture. The artist received the nickname the "cantora do If" (The "It" singer ${ }^{12}$ ), denoting a special charisma in the eye of her contemporaries, making her stand out from the others. This 
aspect was related both to her trajectory, which was based on a combination of popular culture, the flaunting of jargon and expressions from the streets of Rio de Janeiro, and her image as a representative of a modern femininity, in negotiation with the moral codes and racial tensions of her period.

In the international phase of her career, after appearing in the Broadway musical revue Streets of Paris, Carmen took with her the stylized wardrobe of the Baiana with its turbans and adornments, as well as her musical group the Bando da Lua. These elements had a strong influence on her first appearances in U.S. theater. After that, her exotic apparel opened doors to many contracts with clothing manufacturers, and generated a clandestine appropriation of her image by various fashion sectors in the United States (CASTRO, 2005, p. 223).

Carmen's style soon invaded large department stores. Macy's used Carmen's name in its advertising campaign in 1939 and Teller's created mannequins with poses and faces inspired by the Brazilian entertainer. Carmen hired the Italian designer Ferragamo in New York to make the platform shoes that she had been using since 1934 in Rio de Janeiro. As Lisa Shaw affirmed, "until Carmen became associated with them, platform shoes were considered by the local stores as too exotic for American women" (2013, p. 91).

In a period in which a blond movie star was the aesthetic reference for a romantic character, Carmen Miranda had growing prominence in U.S. cinema. Her exoticism, already part of the representations of Latin America, was reinforced with the Baiana wardrobe, accentuating the "excess" and the tropicality of her characterization. An increasing number of complexly stylized and sophisticated versions of the Baiana were created. Her clothes were characterized by Robert Sullivan in the Sunday News (November 16, 1941, Shubert Archive,) as "barbaric and brilliant", leaving men "dazed" and women "disturbed".

According to Ovalle, "As white women entered the labor force, Miranda's exotic appearance provided an easy-toadopt look for women eager to 'spice up' their work uniforms with 'colorful floral scarves... bright red lipstick and costume jewelry' (Berry 2000, 126)" (OVALLE, 2011, p. 68). Carmen's Latinness served as a mid point between whiteness, which was symbolically conceived to lack the sexual attraction and sensuality associated to blackness, Ovalle affirmed. This allowed white women to consume items that would make them sensual, without a negative association to blackness. Thus, Carmen Miranda opened a path for future U.S. performers, influencing the socially accepted moral limits of femininity.

In the Brazilian context, Carmen's characterizations revived a certain systematic critical disdain for her 


\begin{abstract}
${ }^{13}$ The Brazilian press at times criticized Carmen for becoming Americanized and at times blamed the directors of her films for problems in the interpretation of Brazilians, despite her great box office success. Supposedly, it was no longer the issue of Carmen Miranda, but of a Latin American caricature or of an artist "inebriated by the perfume of American money". Journalists and letters from readers criticized Carmen for singing sambas "that smelled like rhumbas", contrary to what the "Ambassador of Samba" promised when she left Rio de Janeiro for New York (Archive of the Biblioteca Jenny Klabin Segall).
\end{abstract}

performances, ${ }^{13}$ although she continued to attract considerable interest and worship from the Brazilian public. Carmen Miranda's success also stimulated the reverberation of her Baiana costume in elite contexts. Many women, stimulated by advertising and the market for carnival costumes, incorporated Carmen's Baiana, inspired by the idea of a Brazilian femininity, given prestige by Hollywood films.

Even at the Municipal dance, the most selective of all that were held in Rio de Janeiro (...) there was a clear majority of "bahianas". This truly curious factor is presented in these pages, where we see the most beautiful Baiana who danced at the party in our largest theater. (O Cruzeiro, February 17, 1940, Archives of the Biblioteca Nacional).

The article "As bahianas invadiram o Theatro Municipal" [Baianas Invade the Municipal Theater], in the $O$ Cruzeiro magazine, registered the dissemination of a costume that had previously been rejected in the gala Carnival dances of Rio de Janeiro. This is indicated by the text remarking on "this truly curious aspect". The specificity of this incorporation in the Brazilian context raises the question of racial boundaries, given that the Baiana was related to a black image. In this sense, the incorporation of the personality of the Baiana was selective and temporary, according to Tania Garcia: "if in the United States the Baiana wardrobe is on the mannequins in the store windows of New York, influencing fashion and women there, in Brazil the clothing was only a costume to be used during the four days of carnival" (2004, p. 118).

The influence of U.S. fashion based on the impact of Carmen Miranda did not change in daily exchanges the racialization of clothing and all the meanings and values attributed to it: "The Baiana outfit, after carnival, continued among us to be found only on blacks who earned their living selling food and fruits on the streets of the capital of the Republic" (GARCIA, 2004, p. 118). In other terms, the turbans and adornments that had so much impact on clothing sales in the United States did not have the same success in Brazil, due to the symbolic universe to which they were related.

Even if limited, the acceptance of the Baiana costume at the elite carnival dances was made concrete through a series of negotiations, involving the stratified market of cultural and entertainment products of the time: from illustrated magazines to clothing stores, carnival decorations and costumes, to the theaters and clubs that offered carnival dances. The racial tensions in the consumption of the Baiana are perceptible in an ad that appeared on the back cover of the magazine $O$ Cruzeiro. The advertisement, for the magazine A Cigarra, had a design that contrasted a black

Estudos Feministas, Florianópolis, 25(1): 269-290, janeiro-abril/2017 281 
14 Maria Celeste Mira (2001) demonstrates that, especially since the end of the second decade of the twentieth century, a new type of reading public was formed in Brazil, based on illustrated magazines that developed techniques and became professional since then at focusing on a literate middle and upper class public. According to Mira, magazines aimed at the family were promoted with a variety of subjects for readers of different genders and ages. Mira affirmed that "many of these publication that developed in Brazil since the 1930s were related to cinema" (MIRA, 2001, p. 27).
Baiana carrying a typical tray of food in the background with a young white woman in the foreground with a hat made of the baiana's tray in reverse. Below the image was written:

The bahiana's tray... (design) has many uses. The beautiful girls of Copacabana discovered that with a certain touch it can become an elegant hat, and if an elegant hat interests you, look for one in the pages of Brazil's most complete monthly magazine. A CigarraMagazine. (O Cruzeiro, February 17, 1940, Archives of the Biblioteca Nacional).

In a magazine aimed at a middle and upper class public, ${ }^{14}$ a radical distinction is found between two types of consumption of the Baiana's hat. The first is black and as representative of the popular classes would be the anti-model and, therefore, obfuscated by the figure in front. The young, white figure, highlighted in front, would be a model "for the beautiful girls of Copacabana". This image made clear that the reference to the Baiana at carnivals had no relation to the black Baiana of the streets of Rio de Janeiro. In the same magazine, another article discussed Carmen Miranda's success on Broadway. To dress like a Baiana meant to incorporate the sensuality, exoticism and tropicality that characterized the modern peculiarly Brazilian woman. Carmen's Baiana, consummated in the gala carnival dances, left behind her "black past", with all its connotative meanings, and pointed to her intimate relation with the world's best known cinema: that of the Hollywood studios.

This appropriation was made at the specific moment of carnival, a period in which women could have greater sexual liberty. This was a relative liberty, given that it was the target of discussion and control found in the press and in the legal knowledge of the time (Cf. CAULFIELD, 2004). Women who frequented the elite leisure spaces could escape from the rigid gender controls, incorporating new values that came to associate Brazilianness with a national femininity. The incorporation of the Baiana in the carnival dances was articulated with new standards of Brazilianess that were imposed on women, revealing the demarcation of racial differences.

\section{Carmen Miranda camp: the dislocating appropriation of an extravagant artist}


In these lyrics from the song The Lady in The Tutti-Frutti Hat, interpreted by Carmen Miranda in the movie The Gang's All Here (1943), the entertainer defends herself from a supposed accusation that she dresses exaggeratedly gay, alleging that this style corresponds to her natural spirit. The iconography of her character, in turn, is distant from that which is considered as reasonable for common clothing, associating a transgressive, supposedly "natural" sensuality to Latin American women, with her performance based on exaggeration and the artificial composition of her clothes. Thus, we have the vocal and corporal expression of authenticity (the "natural") contrasting with her exaggerated ("cultural") outfit, paradoxically conjugating spontaneity and artificial extravagance, creating a comic situation.

Humor was part of her trajectory since the first moment she arrived in the new country, in interviews and on the stage. She assumed the stereotype of the Latin American woman, by "playing" with her inability to speak English, her declared interest in U.S. men and an insatiable hunger. Carmen took advantage of her mistakes in English. Even when she already spoke English very well, she reinforced her accent and the pronunciation errors. Since she came from another context, she had a certain distancing from the symbolic framing that situated her and could use her stereotype for comic purposes. Aware that she would not be asked to play roles other than those with comic aspects and caricatures of her film persona, Carmen came to emphasize and exaggerate them in order to dislocate them. After a certain moment in her career, Carmen came to perform a self-parody in films and nightclub presentations. One interesting example is her performance of the song I Make my Money with Bananas, whose lyrics make fun of the fact that her career was closely linked to bananas. In her performances, she would remove the bananas from her turban, and take them to the public. She would take off her sandals to show she was short, and showed her hair, saying there is something under the turban, etc. (Cf. CASTRO, 2005, p. 435). In addition to the self parodies, various artists made parodies of her in the theater and movies. She personally helped some artists to appropriate the character of Carmen Miranda, as in the performance of Mickey Rooney in the film Babes on Broadway.

From the Baiana in Brazil to a Latin American performing in the United States, Carmen Miranda had a talent for incorporating representative symbolic elements, and moreover for altering them in her favor and giving them new meanings. Through her negotiations with the press and public appearances, with her stylizations and exaggerations in the production of clothing and facial expressions, and even with her dialogical ability, she sedimented other meanings to the 
${ }^{15}$ This does not involve something spatially limited, but something widely found. In particular, one spectacle that had surprising success, This is the Army, and became immensely popular in the United States, was presented on Broadway for nearly two months and with imitations in other fields even outside of the country. Between October 1942 to August 1943 the spectacle toured the United States, highlighted by a presentation to President Franklin Delano Roosevelt, who declared his pleasure to see a soldie personifying Gypsy Rose Lee, in a strip-tease (BÉRUBÉ, 1990, p. 78). ${ }^{16}$ One homosexual entertainer said "[...] He could enjoy seeing - or being - the real man in the dress kissing, dancing with, or singing love songs to other men and then enjoy the subsequent wealth of usually unintended double entendres, transforming every aspect of the performance into a homosexual subplot. When he knew there were other gay men in the cast or audience, with a wink or a knowing glance he could share his secret enjoyment with them, expanding his solitary appreciation into group experience. In this way drag performances, wherever they were held, inadvertently opened up a social space in which gay men expanded their own secret culture. The joke was on the unaware members of the audience - a subplot about homosexuality was being created right before their eyes and they didn't even know it" (BÉRUBÉ, 1990, p. 72).

${ }^{17}$ The first personification of Carmen in the movies was made by Mickey Rooney in Babies on Broadway (1941), a Busby Berkeley film made by MGM. Rooney's personification was preceded by other parodies of Carmen in theater and many others followed in the movies, characterizing in a comic way some elements sedimented in Carmen's performances such as the use of turbans, her exoticism and tropicality.
Brazilian and Latin American iconography, with the figure of the exported Baiana.

In her dialogs with various audiences, a curious form of reading of Carmen Miranda appeared in the unique appropriation of her persona in the armed forces. At male bases and camps without women, men not only conducted services considered to be those for women, but also played women on stages. ${ }^{15}$ The predominant reception in the media and in the armed forces, within a mainstream perspective, interpreted these spectacles as comedy, part of a strategy to promote entertainment, raise morale and the integration needed among soldiers (BÉRUBÉ, 1990). Accidentally, Carmen wound up producing "a temporary refuge where they could let their hair down to entertain their fellows" (BÉRUBÉ, 1990, p. 67-68). The relations between actors and spectators produced readings as drag performances, and suggested homosexual meanings to the narratives. ${ }^{16}$

Bérubé (1990) pointed to the existence of a publication called "Blueprint Special" from 1944 about the show "Hi Hank!" which included five pages that presented male characters of Carmen Miranda. According Bérube, in April 1941 a writer from Theather Arts Magazine even reported that armed forces personnel were tired of male interpretations of Carmen Miranda and "desperately" declared the need for greater variety (BÉRUBÉ, 1990, p. 89). More than a specific addendum, the tie between Carmen Miranda and this public reveals an interesting facet that helps us understand crucial aspects of the agencying of Carmen Miranda and of the multiple and dissonant dynamic of the mass cultural products. It involves an important aspect whose consequences can be perceived until today, with Carmen Miranda still conceived of as a "gay icon" especially among older generations.

Among the various parodies of Carmen, I highlight that made by a soldier who performed in theaters and military camps during World War II, Sasha Brastoff. Brastoff's interpretation (which I discovered in a series of photos in a file in the One Lesbian and Gay Archive of Los Angeles, and in which he performed various characters as a drag queen) became so famous that it was presented in a 1946 film about the armed forces, "Winged Victory". Brastoff did not parody Carmen by emphasizing a Latin American image with her hats of tropical fruits, as did most of the parodies of her in the movies. ${ }^{17}$ Brastoff explored one of her characteristic artistic elements: stylization. The artist maintained Carmen's style of dress, but his costume substituted the fruits with silverware and a U.S. army uniform, even accentuating the exaggerated platform shoes used by Carmen. This shrewdly placed Carmen Miranda into the U.S. army in a drag interpretation. 
Brastoff's interpretation of Carmen Miranda leads us to think about her importance in the gay subculture and in the drag world. There is something in this relationship, which has already been widely studied by various researchers (CLETO, 1999; DYER, 2004; HALPERIN, 2013) in attempts to understand why many men who identify themselves as homosexuals experience the culture through a peculiar reading, in particular, one based on an identification with certain actresses and singers. This involves what has been conceptualized as a sensibility, a taste, a genre of language or even a discourse known as camp, which was originally an English term specific to a homosexual subculture which in turn designated a communication media restricted to the initiated.

Camp, according to Susan Sontag (1999), is characterized by the opposite of a valorization of content, and establishes a "vision of the world in terms of style", the world as an aesthetic phenomenon, evaluated "in terms of a degree of artifice, of stylization", something that makes movie stars with accentuated and exacerbated femininity the greatest examples of gay icons and a characteristic in performances by drag queens. While Sontag (1999) understands that camp has an essentially apolitical nature, the recent bibliography explores how it can be constituted as a form of subversion by emphasizing an artifice that exposes an arbitrariness that is naturalized by means of culture, and gender norms in particular (Cf. CLETO, 1999).

These individuals who share a camp manner live in heteronormative societies that are characterized by a violently heterosexual public sphere, in which "to pass for hetero" is an important strategy of survival for non heterosexual men. This being the case, they tend to become more conscious, even if in a way that is not critical or reflective, of gender identities as performative, and acquire a special sensibility for personification (BABUSCIO, 1999; HALPERIN, 2013). For this reason, attention to the superficial and to style are central to a camp perspective.

While Susan Sontag revealed the character of the world as theater, a fundamental aspect of camp, Fábio Cleto explored the important character that the stage had for the queer normative ruptures.

We have seen that the conditions which produce a camp effect are by and large the impermanent building of an interpretative theatrical stage, and that these conditions also constitute the status of camp itself, which shares the same provisional, performative and processual premises, and ends up being a queer (unstable, twisted, disorganic), nomadic, in(sub)stantial or ephemeral discursive architecture: in short, an effect of performativity itself (CLETO, 1999, p. 32). 
Stylization and performance on stage are characteristics of the career of Carmen Miranda, as well as their appropriations. It is from the stages that she created her characteristic traits, whether costumes such as turbans and ornaments, or the movements of her hands and waist, which are easily reproduced. Carmen and her personifiers could even accentuate this or that aspect of her characteristics, generating comic effects by playing with a supposed authenticity constructed by the artist. To dress as Carmen was a way to explore the world as theater, identity as parody and authenticity as arbitrary. In this sense, it involved a language that is characterized by a close affinity with queer theories that emphasize the performative aspect of identities. Judith Butler (2003) found parody to be a means to subvert identity norms that exposes the social arbitrariness of that which is naturalized by discourse and practice. This does not involve any parody: "the parodistic shift, the laugh of parody, depends on a context and on a reception in which subversive confusion can be encouraged" (BUTLER, 2003, p. 198). In Butler's logic, gender is a performative construction that does not exist in a natural or original state - it is the fruit of stylized repetition, which in turn is regulated by social norms. Butler (2003) begins with the description of a personification of Garbo from a much earlier text by Esther Newton (1999), which focused on an ethnographic analysis of the drag world of post war North America. In this space, the performance of incoherence is seen as a central point on the stage, when an individual of anatomically masculine sex interprets the feminine, emphasizing ambiguous aspects of gender, transforming gender from a supposed ontological priority into a performative fabrication.

The homosexual public's public identification with Carmen Miranda and with camp does not occur without reason. Her exaggeration, stylization and self-parody produced a distancing from the stereotype of Latin American women or destabilized essentialist ideas of identities, in the vision of this public. Her stylized characters - who maintain the original form of the Baiana with distinct characterizations - emphasize stylization as a trait present in the construction of identities and thus suggest the intuitive perception of the cultural and arbitrary construction of identities. If Carmen Miranda could interpret a role and parody it, why couldn't others? Carmen Miranda was not only an object of appropriation by men who interpreted her, she participated in this process, helping various actors to personify her, and even appeared at one of Sascha Brastoff's presentations in a theater, and said that he interpreted Carmen Miranda better than she did (The Washington Post, May 24, 1945, Proquest). Thus, she showed certain audiences that Carmen Miranda was, in reality, a role. 
What Sascha Brastoff's performance indicates is the possibility for a dislocating language that is understood only among peers and which uses mainstream means of expression to subvert them. It involves a subversive reading specific to a homosexual experience in a heteronormative society, within a key institution of heterosexual masculinity (the armed forces) and by means of promotion of Hollywood cinema. In other terms, the very institutions that produce the heteronormativity are open to its subversion, given that it is not a closed system immune to questioning.

Brastoff took Carmen's humor seriously, and by emphasizing the cultural arbitrariness of meanings, simultaneously questioned the heteronormative values of cinema and of the armed forces, even with financing from both. The figure of the soldier was transformed, for the laughs of those who could decipher the codes, into a drag version of Carmen Miranda. Carmen's interpretation in Winged Victory demonstrated that non normative experiences were present in a connotative form in cinema, creating possibilities for subjectivation in disaccord with the social norms, attesting to the fact that mainstream cultural production also creates dissident meanings, even if not intentionally (DOTY, 1993).

\section{Final considerations}

By analyzing consumption as a fundamental aspect of Carmen Miranda's trajectory, my intention was to focus on how mass culture and the grasping of its meanings are marked by ambiguities and dissonances. More than emphasizing the relationship between Carmen Miranda and the representations of Brazilianess or the stereotype of the Latin American woman, I sought to analyze how the interpretation of her meanings is more diverse and depends on their reception. To consider the publics as a constituent part of the construction of the media image means understanding that they "can select from the complexity of the image, the meanings and sentiments, the variations, inflections and contradictions that work for it" (DYER, 2004, p. 4).

The semiotic construction of a movie star has a logic specific to the workings of the film industry within a capitalist economy, although it is not restricted to economic problematics. Carmen handled her trajectory from Brazil with elements marked first in Brazilian and then in continental representations, characterized by an intersection between categories of gender, race and sexuality. From the Baiana to its overlapping by the Latin American woman, with the repetition of symbolic elements with a specific history, Carmen wound up shifting them and giving them new meanings. Her reception by the female public and by the male homosexual 
public allowed focusing on creative aspects and dissident possibilities of representations and identifications within the mass culture, which is invariably marked by multiplicity and subversive appropriations.

As we saw, in the U.S. context, an image of Carmen Miranda was forged based on a Latin American stereotype with a history in Hollywood movies specific to the representations that placed it at a subaltern level. Nevertheless, as I sought to address, the construction of Carmen Miranda's image was not passive, but had active participation from the actress, singer and entertainer. Using the concept of performativity (BUTLER, 2003), it is possible to consider how by means of repetition, stylization and humor Carmen was able to alter her meanings, although within certain imposed limits.

Through her negotiations with the press and public appearances, whether in presentations or in private life, she wound up strengthening various meanings that became part of the Brazilian and Latin American iconography. Given the complexity of the universes and symbolic strategies with which the Brazilian artist led, she established different types of reception, related with social experiences that established distinct relations with her image and performances. The multiplicity of meanings that she triggered, invading private lives via mass media, allowed her image to be read and used in various manners and by different subjects, establishing a paradigmatic and transnational cultural icon.

\section{References}

ADELMAN, Miriam. A Voz e a Escuta: encontros e desencontros entre a teoria feminista e a sociologia contemporânea. Curitiba: Blucher, 2009.

ANDERSON, Benedict. Comunidades Imaginadas, Lisboa: Edições 70, 1991.

BÉRUBÉ, Allan. Coming out under fire. The History of gay men and women in World War II. The University of Carolina Press, Chapel Hill, 1990.

BRAH, Avtar. "Diferença, Diversidade, Diferenciação". In: Cadernos Pagu. Campinas, Núcleo de Estudos de Gênero Pagu, n. 26. p. 329-376, 2006.

BUTLER, Judith. Problemas de Gênero: Feminismo e Subversão da Identidade. Rio de Janeiro: Civilização Brasileira, 2003.

CASTRO, Ruy. Carmen: uma biografia. São Paulo: Companhia das Letras, 2005.

CAULFIELD, Sueann. Em defesa da honra: moralidade, modernidade e nação no Rio de Janeiro (1918-1940). Campinas, SP: Editora da Unicamp, Centro de Pesquisa em História Social da Cultura, 2000. 
CEVASCO, Maria Elisa. Dez lições sobre estudos culturais. São Paulo: Boitempo Editorial, 2003.

CLETO, Fabio (org.). Camp: Queer Aesthetics and the Performing Subject. The University of Michigan Press. Ann Arbor. 1999.

DAVIS, Darién J. White Face, Black Mask: Africaneity and the early social history of popular music in Brazil. Michigan State University Press, 2009.

DOTY, Alexander. Making things perfectly queer: interpreting mass culture. University of Minnesota Press. Minneapolis, London, 1993.

DYER, Richard. Heavenly Bodies: Film Stars and Society. Routledge. London \& New York. Second Edition. 2004. . Stars. London: British Film Institute, 1979.

FENERICK, José Adriano. Nem do Morro, Nem da cidade: as transformações do samba e a indústria cultural. 19201945. São Paulo: Annablume/Fapesp, 2005.

GOMES, Tiago de Melo. "Massais, mulatas, meretrizes: imagens da sexualidade feminina no Rio de Janeiro dos anos 1920". Cadernos Pagu (UNICAMP), Campinas, v. 23, p. 121-147, 2004.

HALL, Stuart. "A centralidade da cultura: notas sobre as revoluções culturais do nosso tempo". Educação \& Realidade, Porto Alegre, v. 22, n. 2, p. 15-46, jul./dez. 1997.

HALPERIN, David. M. How to be gay. Cambridge, Massachusetts: Belknap Press, 2012.

JUNIOR, Abel Cardoso. Carmen Miranda: a cantora do Brasil. São Paulo: Edição particular do autor, 1978.

MARTIN-BARBERO, J. Dos meios às mediações: comunicação, cultura e hegemonia. Rio de Janeiro: Editora da UFRJ, 2009.

MATTELART, Armand; NEVEU, Érik. Introdução aos Estudos Culturais. São Paulo, Parábola, 2004.

MENDONÇA, Ana Rita. Carmen Miranda foi a Washington. Rio de Janeiro/São Paulo, Record, 1999.

MIRA, Maria Celeste. O leitor e a banca de revistas: a segmentação da cultura no século XX. São Paulo: Olho d'água/Fapesp, 2001.

MISKOLCI, Richard. Desejo da Nação: masculinidade e branquitude no Brasil de fins do XIX. 1. ed. São Paulo: Annablume, 2012.

NEWTON, Esther. "Mother Camp: Female Impersonators in America" In: CLETO, FABIO (org,). Camp: Queer Aesthetics and the Performing Subject: A Reader. Edinburgh University Press, 1999.

ORTIZ, Renato. Cultura Brasileira e Identidade Nacional. São Paulo: Editora Brasiliense, 1985. 
OVALLE, Priscilla Peña. Dance and the Hollywood Latina: Race, Sex and Stardom. Rutgers University Press, New Brunswick, New Jersey, and London, 2011.

PEREIRA DE SÁ, Simone. Baiana Internacional: O Brasil de Carmen Miranda e as lentes de Hollywood. Tese de Doutorado do Programa de Pós-Graduação em Comunicação, UFRJ, Rio de Janeiro, 1997.

ROBERTS, Shari, "'The Lady in the Tutti-Frutti Hat': Carmen Miranda, a Spectacle of Ethnicity", Cinema Journal, 32:3, Spring, 1993.

ROBERTSON, Pamela. Guilty Pleasures: Feminist Camp from Mae West to Madonna. Durham, N. C.: Duke University Press, 1996.

SALIH, Sara. Judith Butler e a teoria queer. Belo Horizonte: Autêntica Editora, 2012.

SHAW, Lisa. Carmen Miranda. Palgrave Macmillan, London and New York, 2013.

SCHPUN, Mônica Raisa. "Carmen Miranda, uma star migrante". Revista de Antropologia, São Paulo, USP, v. 51, n. 2,2008, p. $451,471$.

SEVCENKO, Nicolau. "A capital irradiante: técnica, ritmos e ritos do Rio". In: SEVCENKO, N.; NOVAIS, F. (Orgs.). História da Vida Privada no Brasil: da Belle èpoque à era do rádio. 3. ed. São Paulo: Companhia das Letras, v. 3, p. 513-619, 1998.

SOLBERG, Helena. Carmen Miranda: Bananas is my business. Estados Unidos, 1995.

SONTAG, Susan. "Notes on 'Camp'”. In: CLETO, Fabio (Org.). Camp: Queer Aesthetics and the Performing Subject - $A$ Reader. The University of Michigan Press. Ann Arbor. 1999.

[Recebido em 12/05/2016

e aceito para publicação em 21/09/2016]

Fernando de Figueiredo Balieiro (fernandofbalieiro@gmail.com). Professor Adjunto do Departamento de Sociologia e Política e do Programa de Pós-Graduação em Sociologia da Universidade Federal de Pelotas (UFPel). Doutor (2014) e mestre (2009) em Sociologia pela Universidade Federal de São Carlos (UFSCar), é licenciado e bacharel em Ciências Sociais pela Universidade Estadual Paulista - UNESP/FCL - Araraquara (2005). Realizou Doutorado sanduíche na University of California em Santa Cruz (UCSC), no programa Film\& Digital Media e pós-Doutorado em Sociologia na UFPel (2015). Tem experiência na área de Sociologia, ałuando, especialmente, na temática dos Estudos Culturais, representações, gênero, raça e sexualidade. Como docente, destaca suas atuações na UAB UFSCar como professor conteudista, formador de tutores, tutor de referência e tutor virtual. É pesquisador do Quereres - Núcleo do Pesquisa em Diferenças, Gênero e Sexualidade da UFSCar e um dos líderes do Núcleo Interseccionalidades de pesquisa em gênero, raça e sexualidade da UFPel. 